Columbia Law School

Scholarship Archive

2014

\title{
Exporting Standards: The Externalization of the EU's Regulatory Power via Markets
}

Anu Bradford

Columbia Law School, abradf@law.columbia.edu

Follow this and additional works at: https://scholarship.law.columbia.edu/faculty_scholarship

Part of the Comparative and Foreign Law Commons, European Law Commons, International Law Commons, and the Law and Economics Commons

\section{Recommended Citation}

Anu Bradford, Exporting Standards: The Externalization of the EU's Regulatory Power via Markets, INTERNATIONAL REVIEW OF LAW \& ECONOMICS, Vol. 42, P. 158, 2015; COLUMBIA LAW \& ECONOMICS WORKING PAPER No. 535 (2014).

Available at: https://scholarship.law.columbia.edu/faculty_scholarship/1972

This Working Paper is brought to you for free and open access by the Faculty Publications at Scholarship Archive. It has been accepted for inclusion in Faculty Scholarship by an authorized administrator of Scholarship Archive. For more information, please contact scholarshiparchive@law.columbia.edu. 


\title{
Exporting standards: The externalization of the EU's regulatory power via markets
}

\author{
Anu Bradford* \\ Columbia Law School, Jerome L. Greene Hall, 435 West 116th Street, Room 927, New York, NY 10027, USA
}

\section{A R T I C L E I N F O}

\section{Article history:}

Received 30 August 2012

Received in revised form 4 June 2014

Accepted 27 September 2014

Available online 6 October 2014

\section{Keywords:}

Regulation

Brussels effect

California effect

European union

Regulatory power

Regulatory race

\begin{abstract}
A B S T R A C T
This Article examines the unprecedented and deeply underestimated global power that the EU is exercising through its legal institutions and standards, and how it successfully exports that influence to the rest of the world. Introducing the notion of "the Brussels Effect," the Article shows how market forces alone are sufficient to convert EU standards into global standards. Without the need to use international institutions or seek other nations' cooperation, the EU has a strong and growing ability to promulgate regulations that become entrenched in the legal frameworks of developed and developing markets alike, leading to a notable "Europeanization" of many important aspects of global commerce. This Article identifies and explains the precise conditions for and the specific mechanism through which this externalization of EU's standards unfolds. Enhanced understanding of this dynamic explains why the EU is currently the only jurisdiction that can wield unilateral influence across a number of areas of law, ranging from competition and privacy to health and environmental regulation. This understanding also helps explain why certain regulations can be externalized via markets while others rely on the EU's ability to exert influence through its political agency. The Article further disputes the notion that the EU's ability to externalize its rules would reflect "regulatory imperialism," as critics have suggested. Instead, it argues that the EU's external regulatory influence has emerged largely as an inadvertent byproduct of its internal goal to create and strengthen the single market. The EU's regulatory authority has been further solidified as the markets, other states, and international institutions have been able to do little to constrain Europe's global regulatory power. In the end, as much as the rise of the EU's regulatory power is a product of its pursuit of internal goals, any limits to this power are likely to stem from within the EU itself.
\end{abstract}

(c) 2014 Elsevier Inc. All rights reserved.

\section{Introduction ${ }^{1}$}

It is common to hear Europe described today as a power of the past. Europe is perceived to be weak militarily. Its relative economic power is declining as Asia's is rising. Its common currency may be on the verge of disintegrating. On the world stage, the European Union is thought to be waning into irrelevance due to its inability to speak with one voice. Given its seemingly declining power status and inability to get its way alone, the EU is perceived as needing to retreat to weak multilateralism and international institutions (Rubenfeld, 2004; Bradford and Posner, 2011). ${ }^{2}$

\footnotetext{
* Tel.: +1 2128549242

E-mail address: abradf@law.columbia.edu

1 A longer version of this article, entitled "The Brussels Effect," was published in 107 Northwestern University Law Review 1 (2012).

2 See European Commission, Communication, The European Union and the United Nations: The choice of multilateralism, at 1.1, COM (2003) 526 final (Sept. 10, 2003).
}

Contrary to this prevalent perception, this Article highlights a deeply underestimated aspect of European influence that the discussion on global power politics overlooks: Europe's unilateral power to regulate global markets. The European Union sets the global rules across a range of areas, such as food, chemicals, the environment, competition, and the protection of privacy. EU regulations have a tangible impact on the everyday lives of citizens around the world (Mitchener, 2002; Scheer, 2003). ${ }^{3}$ Few Americans are aware that EU regulations determine the make-up they apply in the morning, the cereal they eat for breakfast, the software they use on their computer, and the privacy settings they adjust on their Facebook page. And that's just before 8:30 a.m. The EU also sets the rules governing the interoffice phone directory they use to call a co-worker. EU regulations dictate what kind of air conditioners Americans use to cool their homes and why their children no

\footnotetext{
3 See Regulatory Imperialism, WALL ST. J., Oct. 26, 2007 at 1; Case COMP/M.5984 Intel/McAfee (Commission decision of January 26, 2011), 2011 O.J. (C 98) 1.
} 
longer find soft-plastic toys in their McDonalds happy meals. This phenomenon-the "Brussels Effect"-is the focus of this paper.

This Article explains how and why the rules and regulations originating from Brussels have penetrated many aspects of economic life within and outside of Europe through the process of "unilateral regulatory globalization." Unilateral regulatory globalization takes place when a single state is able to externalize its laws and regulations outside its borders through market mechanisms, resulting in the globalization of standards. This process can be distinguished from political globalization of regulatory standards where regulatory convergence results from negotiated standards, including international treaties or agreements among regulatory authorities. It is also different from unilateral coercion, where one jurisdiction imposes its rules on others through threats or sanctions. Unilateral regulatory globalization is a development where a law of one jurisdiction migrates into another in the absence of the former actively imposing it or the latter willingly adopting it.

Critics of globalization have claimed that trade liberalization undermines domestic regulation. Extensive literature has emerged regarding the "race to the bottom" phenomenon-the idea that countries lower their regulatory standards in order to improve their relative competitive position in the global economy (Tonelson, 2000; Murphy, 2004). Recently, many of the assumptions driving this influential literature have been discredited (Vogel and Kagan, 2004). For example, fears of businesses relocating to pollution havens or capital flights following higher levels of corporate taxation have not materialized in large numbers. ${ }^{4}$ Indeed, scholars have shown that international trade has frequently triggered a "race to the top," whereby domestic regulations have become more stringent as the global economy has become more integrated (Vogel, 1997; Vogel and Kagan, 2004; Spar and Yoffie, 2000; DeSombre, 2006). The "California Effect" is a term frequently used to describe this phenomenon: due to its large market and preference for strict consumer and environmental regulations, California is, at times, able to set the regulatory standards for all the other U.S. states (Vogel, 1995; Vogel and Kagan, 2004). Businesses willing to export to California must meet its standards, and the prospect of scale economies from uniform production standards gives these firms an incentive to apply this same (strict) standard to their entire production.

This Article explores the dynamics of the California Effect in a global context. It focuses on the conditions under which a single country can externalize its regulations on other countries. Building upon, yet going beyond, the literature on the California Effect, it argues that the following conditions are necessary for a jurisdiction to dictate rules for global commerce: the jurisdiction must have a large domestic market, significant regulatory capacity, and the propensity to enforce strict rules over inelastic targets (e.g., consumer markets) as opposed to elastic targets (e.g., capital). In addition, unilateral regulatory globalization presumes that the benefits of adopting a uniform global standard exceed the benefits of adhering to multiple, including laxer, regulatory standards. This is the case in particular when the firms' conduct or production is nondivisible, meaning that it is not legally or technically feasible, or economically viable, for the firm to maintain different standards in different markets.

Unpacking the determinants of unilateral regulatory globalization explains why the EU has become the predominant regulator of global commerce and why the EU can successfully export certain norms and not others. The EU has the world's largest internal market, supported by strong regulatory institutions. Trading with the

\footnotetext{
${ }^{4}$ Some examples of the race to the bottom phenomenon however remain. See Millimet, D. \& List, J. (2004). The Case of the Missing Pollution Haven Hypothesis, J. Reg. Econ., 26(3), 239-262.
}

EU requires foreign companies to adjust their conduct or production to the EU standards-which often represent the most stringent standards-else forgo the EU market entirely. Rarely is the latter an option. In addition, companies cannot undermine EU rules by moving regulatory targets to another jurisdiction because the EU primarily regulates inelastic consumer markets as opposed to more elastic capital markets. While the EU regulates only its internal market, multinational corporations often have an incentive to standardize their production globally and adhere to a single rule. This converts the EU rule into a global rule-a phenomenon described as the "de facto Brussels Effect." Finally, after these export-oriented firms have adjusted their business practices to meet the EU's strict standards, they often have the incentive to lobby their domestic governments to adopt these same standards in an effort to level the playing field against their domestic, non-export-oriented competitors. This latter phenomenon converts the de facto Brussels Effect into the "de jure Brussels Effect" (Vogel, 1995).

The Article then moves on to discuss the EU's motivations to externalize its regulations as well as the reasons why foreign corporations and governments generally adhere to, as opposed to challenge, the EU rules. It disputes the critics' notion that the Brussels Effect would reflect the EU's conscious effort to engage in "regulatory imperialism." Instead, it argues that the EU's external regulatory agenda is primarily, even if not exclusively, driven by a set of entrenched domestic policy preferences and the EU's efforts to create an internal market that reflects those preferences. The EU's external regulatory influence has thus emerged largely as an inadvertent by-product of that internal goal rather than as a result of some conscious foreign policy agenda.

The Brussels Effect rarely entails that the foreign targets of EU regulations willingly embrace the EU standards. Instead, foreign corporations would often prefer another rule but find it rational to adjust nonetheless given the opportunity costs of not doing so. At the same time, this dynamic is different from the EU coercing others to adopt its rules. Market forces are sufficient to create "involuntary incentives" to adjust to the rules of the strict regulator. In other words, unilateral regulatory globalization entails the dominant jurisdiction imposing an incentive to adjust, followed by reluctant emulation by market participants. Seen this way, unilateral regulatory globalization is produced through "go-it-alone power" by a dominant regulator, which leaves the adopters no choice but to adhere to the rules else forgo the opportunity to trade with Europe altogether (Gruber, 2000).

Foreign governments are similarly unenthusiastic about the EU's ability to externalize its regulations. Yet they can do little to counterbalance the EU's regulatory hegemony. Countries whose regulatory preferences are overridden by the EU's standards gain nothing by entering into a regulatory race with the EU-outpacing the EU will only leave them with even higher, and hence less desirable, regulatory standards. They also have only an imperfect ability to dampen the EU's regulatory ambitions with sanctions or by resorting to international institutions. This makes them passive spectators of the process where the markets are unleashed to spread the EU norms and entrench them in global markets.

Given the limited ability of foreign governments or international institutions to constrain the EU's regulatory agenda, the greatest check on the EU's regulatory powers comes from within the EU itself. As the EU's powers grow, internal divisions within the EU will increase. The ongoing euro crisis further fuels resentment among the European people, contributing to a severe political backlash. This may eventually lead to a repatriation of some regulatory powers from Brussels back to the Member States. Thus, the EU's own evolving conception of the limits of its regulatory authority will, in the end, define the boundaries of its regulatory reach.

While focusing on the ability of the markets to transform EU standards into global standards, this Article does not claim that the 
Brussels Effect is an exclusive path for global standards. There are different paths to regulatory convergence, all of which can operate in parallel. At times, market forces create sufficient incentivizes for foreign corporations to adopt EU standards. At other times, the EU has to, or it chooses to, resort to political harmonization that entails persuasion or coercion such as diplomacy, trade conditionality or economic sanctions. These other mechanism of regulatory convergence are important but have been discussed extensively elsewhere (Damro, 2012; Büthe and Mattli, 2010, 2011; Sabel and Zeitlin, 2008; Linos, 2011). The purpose of this contribution is not to review the existing literature on those other mechanisms of regulatory influence but explain the logic of the Brussels Effect, which is less well understood. However, this Article seeks to explain when and why the Brussels Effect presents a more attractive method of influencing global regulatory environment compared to these alternatives. It explains the distinct advantages that the market based harmonization has over political harmonization for the EU but also explain why, despite these clear advantages, the EU continues to embrace multilateralism and pursue political harmonization in some instances.

This Article contributes to the scholarship on international regulatory convergence (Drezner, 2005; Simmons, 2004). It also engages directly with the literature on the direction of possible regulatory races, such as whether the race to the top or the race to the bottom is more pervasive in explaining regulatory outcomes globally. While the Article builds on the existing theory of the California Effect, it goes beyond it in two critical ways. First, it seeks to outline the precise conditions that allow an upward regulatory convergence to take place. While the California Effect is recognized as a phenomenon, existing scholarship has not explained its actual scope beyond anecdotes and individual examples. Second, it uncovers and explains a perhaps most significant example of the California Effect-its global occurrence-that has been undertheorized and underestimated as an empirical phenomenon.

The existing scholarship on the California Effect has recognized the importance of market size and scale economies as a source of jurisdiction's external regulatory clout. At the same time, it has failed to acknowledge factors such as regulatory capacity and inelasticity as key components of the theory, and it has overlooked criteria other than scale economies as factors that can prevent a company from producing different varieties for different markets. Thus, the discussion of the Brussels Effect provides a more nuanced theory of the conditions under which a single jurisdiction can exert regulatory influence outside its borders. Second, the global regulatory clout that the EU exercises via the Brussels Effect has been vastly underappreciated. Scholarship on international regulatory convergence has focused on a country's market size as the best proxy for its external regulatory influence (Drezner, 2005; Wirth, 2007; Damro, 2012). This Article, however, shows that market power alone does not explain international regulatory outcomes. A more accurate and complete understanding of the conditions underlying the Brussels Effect explains why the EU, as opposed to any other large economy, can unilaterally supply global standards.

In addition, this Article makes the following contributions: first, it shows that the Brussels Effect is more pervasive and widespread than thus far recognized. The current literature on upward regulatory races focuses almost exclusively on environmental regulation (Holzinger and Sommerer, 2011). Even there, scholars claim that regulatory globalization through the California Effect is constrained to "only a highly limited subset of environmental laws" and largely excluded in the case of production (as opposed to product) standards or consumer protection (Vogel and Kagan, 2004; Scharpf, 1996; Swire, 1996; Macey, 2003). This view fails to capture the full impact of the phenomenon. This Article shows that the logic of the Brussels Effect reaches a broad range of regulations aimed at protecting the interest of consumers and the general public, whether those regulations relate to product, environmental, privacy or competition standards.

Second, the existing literature focuses on the race to the top that takes place when a lax foreign regulator formally adopts the strict rule of the lead regulator (Vogel and Kagan, 2004; Simmons, 2004; Braithwaite and Drahos, 2000). This attention to "de jure regulatory convergence" fails to account for an important phenomenon that takes place in the absence of formal changes to legal rules. In reality, this type of formal "trading up" often fails to occur. Instead, we typically see only a "de facto regulatory convergence" whereby much of global business is conducted under unilateral EU rules even when other states continue to maintain their own rules. This is true, for instance, with respect to U.S. antitrust (competition) laws, privacy laws, and rules on food safety. Unilateral regulatory globalization does not need to elicit a formal regulatory response from another nation-often there is no race to the top or de jure Brussels Effect. The EU law governs whether other countries follow suit or not. Seen in this light, the Brussels Effect is more about one jurisdiction's ability to override others than it is about triggering an upward regulatory race.

It is true that at times this de facto Brussels Effect is reinforced with a de jure Brussels Effect. This is the case when other countries' legislators affirmatively adopt the EU's strict standards. But even here, the path to regulatory convergence follows a sequence different from what we have become accustomed to in other contexts. Corporations' de facto adjustment to the EU rules paves the way for legislators' de jure implementation of these rules rather than the other way around. Thus, the implementation problem of the de jure Brussels Effect is solved from the outset.

Third, the theory of unilateral regulatory globalization departs from existing scholarship on the relationship between regulatory convergence and regulatory power. Daniel Drezner has argued that great-power consensus leads to regulatory convergence whereas great-power disagreement leads to regulatory divergence and the emergence of rival standards (Drezner, 2005). Which rival standard trumps the other depends on the regulatory powers' relative ability to seek allies supporting their respective regulatory preferences and reach a tipping point after which the rival states need to switch standards. In contrast to Drezner, this Article shows that de facto convergence can take place in the midst of a great-power disagreement. When the conditions for the Brussels Effect exist, rival standards between two equal powers fail to materialize. Instead, the outcome of the regulatory race is predetermined: the more stringent regulator prevails.

Finally, prevailing theories on regulatory globalization explain the emergence of regulatory convergence as a result of cooperation or coercion. The Brussels Effect differs because it falls between the two. Beth Simmons, for instance, shows how in the case of capital adequacy requirements and accounting standards for public offerings, countries with lenient regulatory standards have an incentive to adopt other countries' stricter standards in order to attract foreign capital (Simmons, 2004). This amounts to a marketdriven race to the top as the followers have a clear economic incentive to adopt the desirable rules that leave everyone better off. In contrast, unilateral regulatory globalization is rarely a process of voluntary harmonization: foreign corporations would often prefer another rule but find it rational to adjust nonetheless given the opportunity costs of not doing so. Yet the EU is not coercing others to adopt its rules either. Market forces are sufficient to create "involuntary incentives" to adjust to the rules of the strict regulator. In other words, unilateral regulatory globalization entails the dominant jurisdiction imposing an incentive to adjust, followed by reluctant emulation by market participants.

In addition to advancing the literature on regulatory globalization, this Article makes a contribution to the literature on state power in international relations. While traditional tools of power 
have waned in importance-it is increasingly difficult to exert influence through raw military power or rely on economic sanctions or conditional incentives-regulatory power that the EU possesses is more durable, more deployable, and less easily undermined by others (Gelb, 2010).

This Article proceeds as follows. Section 2 outlines the conditions under which the Brussels Effect takes place. Section 3 discusses the reasons that cause the EU to externalize its regulations and explains when this externalization takes place through markets as opposed to through the EU's political agency. Section 4 discusses the reasons that cause foreign corporations to adopt EU rules and foreign governments to yield to, rather than counterbalance, the Brussels Effect. The Conclusion focuses on the implications of the EU's global regulatory role within and beyond the EU, and evaluates the likelihood of its persistence in the future. The purpose of this Article is descriptive. This Article will not discuss whether strict regulatory standards are efficient or desirable. Instead, it provides an account for why and how trade liberalization can lead to stringent standards, why this follows a process of unilateral regulatory globalization, why today these global standards are set predominantly by the EU, and why the rest of the world can do little about it.

\section{Conditions for unilateral regulatory globalization}

This section lays the theoretical foundation for the Brussels Effect. It identifies the conditions for and the mechanism through which the externalization of one state's standards unfolds. These conditions also explain why some regulations, but not others, are conducive to the Brussels Effect. They also explain why the EU is currently the predominant regulatory regime that can wield unilateral influence across a number of areas of law and why other large economies, including the US and China, lack this kind of power.

Contrary to existing accounts or EU's market size as the key determinant of its regulatory power, this section argues that market size alone does not determine whether any given country's standards can be globalized. The state must also have the regulatory capacity and the regulatory propensity to convert its market size into actual regulatory influence. By "regulatory capacity," I refer to institutional structures that are capable of producing and enforcing regulations effectively. By "regulatory propensity," I refer to prevailing domestic preferences for strict regulatory standards and the predisposition to regulate inelastic targets. It further argues that only strict standards regulating targets that cannot move-that is, inelastic targets-ensure that a country's regulations will override alternative regulatory standards and make other jurisdictions' regulatory authority obsolete without being punished by markets or constrained by other jurisdictions' regulatory responses. Finally, EU standards become global standards only when the benefits of adhering to a single global standard are greater than the benefits of taking advantage of laxer standards in lenient jurisdictions-in other words, when targets' conduct or production is non-divisible.

\subsection{Market power}

In the global economy, power is correlated with the relative size of any given country's internal market. To secure access to important markets, producers gravitate toward adopting the standards prevailing in those markets (Drezner, 2005; Damro, 2012). The larger the market of the importing country relative to the market of the exporting country, the more likely the Brussels Effect will occur. More accurately, the greater the ratio of exports to the importing jurisdiction relative to sales in the home or third country markets, the more power the importing jurisdiction wields. In contrast, the greater the exporter's ability to divert trade to third markets or increase demand on its home market, the less dependent it is on access to the market of the importing jurisdiction.

Focusing on large domestic markets alone, several states could qualify as potential global standard setters. The EU is the largest economy in the world with a GDP of approximately $\$ 17$ trillion. It consists of a single market with 500 million consumers. The EU has a quarter of the countries' combined Gross National Product (GNP) worldwide, and is the largest importer of goods and services. The EU's internal market is also constantly growing as new countries are joining the EU. Of course, the United States, China, and Japan also possess domestic markets large enough to use access to their markets as leverage. The United States has an economy of over \$15 trillion, almost the same size as the EU, while China has an economy of over $\$ 8$ trillion and Japan has one of over $\$ 5$ trillion.

When assessing the value of market access, foreign corporations also consider the adjustment costs that are necessary to enter the market. A foreign producer will have an incentive to comply with the importing jurisdiction's standard when the benefits of market access outweigh the adjustment costs. The larger the importing market and the lower the adjustment costs relative to the benefits of market access, the more likely that adjustment will take place (Young, 2003). In the case of consumer goods, the benefits of market access are determined by the number and affluence of potential consumers of that product as well as by the opportunity costs of forgoing those consumers. These opportunity costs are particularly high when demand in the corporation's home market or in alternative third markets is limited. The adjustment costs can consist of initial set-up costs and recurring compliance costs. They vary with the significance of cross-border differentials that determine the degree of adjustment and various other compliance costs associated with market access, including licenses or approval processes.

With the world's largest consumer market consisting of a high proportion of affluent consumers, most producers are dependent on their ability to supply the EU market. They may be able to divert part of their exports elsewhere, but few are in a position to abandon the EU market altogether and recoup the forgone revenue in other markets. The distinctly high value of market access to the EU explains why many producers are prepared to incur significant adjustment costs to retain their ability to trade with the EU.

However, the EU's relative market power varies across industries. Insufficient market power therefore always sets boundaries on the EU's global regulatory clout. In instances where adjustment costs are high and alternative markets exist, producers are likely to forgo the EU market and divert trade elsewhere. For instance, the EU has not been effective in externalizing its regulations of automobiles to the U.S. The EU's End-of-life Vehicles Directive, which regulates recyclable components and toxic heavy metals contained in automobiles, has had an insignificant impact on U.S. car manufacturers, who sell virtually no cars to the EU. At the same time, EU regulation has been successfully externalized on Korean and Japanese manufactures that have a strong presence in the European market (Schapiro, 2004).

\subsection{Regulatory capacity}

Large market size alone does not explain a state's ability to project its regulatory preferences on others. Being a regulatory power is a conscious choice pursued by a state rather than something that is inherent in its market size. Not all states with large markets become sources of global standards. The state must also have the regulatory capacity to translate its market power into tangible regulatory influence. Without regulatory expertise and resources to enforce its rules, a country cannot effectively exert authority over market participants-within or outside of its jurisdiction. An important element of regulatory capacity is the 
authority to impose sanctions in case of non-compliance. Only jurisdictions with the capacity to impose significant costs on others by excluding non-complying firms from their markets can force regulatory adjustment (Bach and Newman, 2007; Damro, 2012).

The degree to which a country has regulatory capacity sets important limits to a country's ability to exert global regulatory authority. For instance, many Asian economies are growing at a staggering rate, but it will take time before their GDP growth translates into regulatory experience and institutional capacity to enforce their norms. Thus, acknowledging that sophisticated regulatory institutions are required to activate the power of sizable domestic markets, few jurisdictions outside the U.S. or the EU have the capacity to be regulators with global reach.

The U.S. administrative agencies' capacity to promulgate and enforce rules in the United States is well understood. The rise of the regulatory state in the EU is more recent, yet the institutional developments that accompanied the creation of the single market have bestowed the EU with substantial regulatory capacity (Majone, 1994). The European Commission is the EU's executive arm. The Commission enjoys substantial independent decisionmaking authority. It proposes legislation and ensures that the regulations and directives adopted by the Council and the Parliament are implemented in the Member States. If an individual Member State fails to implement certain regulation, the Commission has the authority to challenge the non-complying Member States before the European courts.

Vesting the EU institutions with the expertise, powers, and resources to guard the common market and to guarantee the rights and responsibilities embedded in European Treaties has been integral to the entire European project. The EU's regulatory capacity has also gradually expanded over the years as a larger set of regulations have become subject to qualified majority voting as opposed to unanimity and as the European Parliament-known for its pro-regulation stance-has gained influence in the EU's legislative process. The EU institutions have acquired these increased powers as a result of the need to further integrate the common market and pursue joint gains from deeper integration.

The EU's regulatory capacity varies across different policy areas. It is most extensive in areas like trade and competition policy, which are central to establishing and strengthening the single market. It is most limited in sensitive areas such as common foreign and security policy, where the individual Member States have retained substantial authority. Naturally, the EU's global regulatory power is limited to policy areas in which the Member States have ceded either exclusive or shared regulatory competence to the EU. However, this is a largely theoretical limit since the EU has, over the years, acquired extensive regulatory capacity in all areas relating to the single market. And these are the very regulations that carry the attributes that lend themselves to externalization. However, there are important policy areas where EU member states have not transferred powers to the EU-including energy policy and corporate taxation-imposing limits on the EU's external influence in these matters.

\subsection{Preference for strict rules}

Regulatory capacity must further be supplemented with the political will to deploy it. Thus, the jurisdiction must also have the propensity to promulgate strict regulatory standards. The existing literature focusing on regulatory capacity often erroneously assumes that the mere existence of this capacity automatically entails the political willingness to employ it. However, while regulatory capacity depends on the sophistication and effectiveness of country's regulatory architecture, the existence of regulatory propensity depends on the prevailing political economy conditions that support a pro-regulation climate. Both are needed for a large market to supply global standards.

The domestic preference for strict regulation is more likely to be found in countries with high levels of income (Guasch and Hahn, 1999). Wealthier countries can better afford pursuing consumer protection at the expense of the profitability of their firms (Guasch and Hahn, 1999; Vogel and Kagan, 2004). This, together with the lack of regulatory capacity, explains why emerging markets are unlikely to exercise rule-making power that would match their growing market size.

But even wealthy countries differ in their predisposition to regulatory intervention. To be a global regulator requires that the state subscribes to strict domestic standards that prevail over more lenient standards by the simple virtue of being the most stringent. Until the 1980s, the U.S. set the global norms in consumer and environmental regulation, leading European firms to adjust to higher standards originating from the U.S. Since then, the roles have been reversed as the EU has increasingly adopted tighter standards of consumer and environmental protection while the U.S. has failed to follow the EU's lead (Lofsted and Vogel, 2001; Laïdi, 2007; Keleman and Vogel, 2007). The only way for the U.S. to supersede the European standards today would be to adopt even higher standards itself-something that it does not consider to be welfare-enhancing and thus in its interest.

The EU's domestic preference for stringent regulation reflects its aversion to risk and commitment to a social market economy. European consumers rank environment and food safety higher than crime and terrorism when asked to evaluate various risks, leading to distinctly high levels of consumer and environmental protection (Laïdi, 2007). ${ }^{5}$ Further, the EU follows the precautionary principle, which dictates that precautionary regulatory action is proper even in the absence of an absolute, quantifiable certainty of the risk, as long as there are reasonable grounds for concern that the potentially dangerous effects may be inconsistent with the chosen level of protection (Harrell, 2010). ${ }^{6}$ In contrast, the risk must first be quantified and found to be unreasonable before regulatory intervention can be justified in the U.S. ${ }^{7}$ The U.S. regulatory agencies are also guided by the cost-benefit analysis, which forces them to substantiate that the benefits of intervention outweigh its costs. To generalize, the U.S. is, therefore, more sensitive to the costs of regulatory action and the "false-positive" regulations whereas the EU emphasizes the costs of inaction and the risks of "false-negatives." These differences often lead to more extensive regulation originating from the EU.

The extent of regulation at the EU level also reflects the efforts by export-oriented EU firms to seek consistent and predictable regulatory frameworks. Uniform regulations have abolished obstacles for doing business within the community. To pursue community-wide regulatory harmonization, the European Commission has often found it easier to "harmonize up" instead of make some member states lower their domestic standards (Vogel, 2012). And once all European firms have incurred the adjustment costs of conforming to common European standards, they have preferred those standards to be institutionalized globally. Hence, to level the playing field and ensure the competitiveness of European firms, EU corporations have sought to export these standards to third countries.

\footnotetext{
5 See also Special Environmental Eurobarometer, "Attitudes of Europeans Towards Environment," available at: http://ec.europa.eu/public_opinion/archives/ ebs/ebs_217_en.pdf.

6 See The European Commission Communication on the Precautionary Principle (February 2, 2000).

7 See Indus. Union Dept., AFL-CIO v. Am. Petroleum Inst. (The Benzene Case), 448 U.S. 607, 642-46 (1980). See also Executive Order 13,563: Improving Regulation and Regulatory Review, 76 Fed. Reg. 3821, 3821 (Jan. 21, 2011).
} 
Of course, the EU also fails to become the source of global standards in areas where the regulatory propensity-the preference for high standards-is absent. This can be true EU-wide, where all or most member states share a preference for low regulation. Often the missing regulatory propensity, however, reflects preference heterogeneity within the EU. For example, the EU is divided on issues like corporate tax harmonization with countries like Ireland (with its $12.5 \%$ corporate tax rate) opposing any step toward tax harmonization and countries like France (with its 34\% corporate tax rate) endorsing common rules. And when it comes to financial regulation of any kind, the U.K.'s opposition is almost guaranteed.

The EU's regulatory clout is also limited in instances where other states have a preference for higher standards. At times, the U.S. prefers higher standards than the EU does. For instance, the U.S.'s Sarbanes-Oxley Act of 2002 ("Sarbanes-Oxley"), targeted at improving corporate responsibility in the post-Enron environment, is widely perceived as establishing the highest global standard for corporate governance. ${ }^{8}$ Where the U.S. opts for strict standards, it can become the source of global standards, assuming the conditions for unilateral regulatory globalization are met. As the U.S.'s recent regulatory pursuits have predominantly targeted the financial sector, it is less likely they will be converted to global standards because of the relative elasticity of capital, as discussed below. For instance, it is debated whether the effect of Sarbanes-Oxley was to ratchet up standards worldwide or to cause U.S. stock exchanges to lose listings of foreign corporations (Coffee, 2002; Sherwoord, 2005). In any event, it is evident that the EU's ability to set the global rules alone is always contingent on it having a preference for the highest rule, which may not always be the case.

In addition to the situation where the relatively permissive EU standard yields to a stricter foreign standard, there may also be situations where one country is stricter on one dimension of a regulation and another country stricter on another dimension. In instances where the corporations are unable to segment the markets, corporations may thus end up adhering to even stricter standards than any single regulator would have required. This situation would be an even more penetrating version of unilateral regulatory globalization, where the global rule would be ratcheted up by a combination of the strictest rules provided by different jurisdictions.

\subsection{Inelastic targets}

Conventionally, we think that markets are able to punish inefficiently stringent regulators. An economic theory of regulatory competition among jurisdictions would suggest that if the EU's regulatory standards were too high, it would lose business and foreign investment to jurisdictions with more attractive regulatory environments. In other words, a state's ability to override another state's preference for lenient standards is compromised if the target can escape the strict regulation by simply relocating. This is the dynamic that triggers races to the bottom as producers seek less constraining regulatory environments.

But this assumption is based on the premise that the targets of the regulation are mobile. The EU avoids this circumvention of its standards by primarily regulating consumer markets, such as product or food safety. When a state regulates targets that are inelastic-as is the case in the EU's regulation of consumer markets-markets have a limited ability to punish that state for any regulatory excesses. Consumers are likely to stay in Europe and businesses have the choice of either providing them with goods

\footnotetext{
8 Sarbanes-Oxley Act of 2002, Pub.L. 107-204, 116 Stat. 745 (July 30, 2002).
}

conforming to EU standards or forgoing the entire market. They rarely opt for the latter.

The inelasticity of consumer markets can be contrasted with a global corporation's strategic decision on where to incorporate or enlist or to a shipping company's decision regarding the flag under which its ship is sailing. While not perfectly elastic, capital is significantly more mobile than consumer markets. If the EU, for instance, tried to harmonize corporate tax levels at excessively high levels, a number of corporations could flee its jurisdiction and incorporate elsewhere. Similarly, if the EU was to impose a tax on financial transactions, trading activity could be diverted to financial centers outside the EU (Chaffin, 2011). Thus, the EU's choice of focusing on consumer markets in its regulatory endeavors thus far has further reinforced its role as a global standard setter whose regulations cannot be undermined by market forces and the elasticity of its targets.

\subsection{Non-divisibility of standards}

The above conditions only ensure that the strict jurisdiction is able to regulate extraterritorially. Meeting these conditions does not, by itself, mean that the strict standard is globalized. The Brussels Effect is only triggered when the exporter, after having converted its products or business practices to comply with the importing jurisdiction's strict standards, decides to apply this new standard to its products or conduct worldwide. In other words, global standards emerge only when corporations voluntarily opt to comply with a single standard determined by the most stringent regulator, making other regulators obsolete in the process.

The exporter has an incentive to adopt a global standard whenever its production or conduct is non-divisible across different markets or when the benefits of a uniform standard due to scale economies exceed the costs of forgoing lower production costs in less regulated markets. Complying with just one regulatory standard allows a corporation to maintain a single production process, which is less costly than tailoring its production to meet divergent regulatory standards (Drezner, 2005; Lazer, 2011). A single standard also facilitates the preservation of a uniform global brand (Vogel, 2012). Thus, unilateral regulatory globalization follows from the non-divisibility of a corporation's production or conduct.

Non-divisibility characterizes often market participants' responses to the EU's health, environmental and other product standards. An illustrative example is European chemical regulation ("REACH"), which applies to all companies seeking to enter the EU market. ${ }^{9}$ Numerous US manufacturers, who would find it too costly to develop different products for different consumer markets, choose to conform their entire global chemical production to the EU standard. Dow Chemicals announced all of its production to be REACH-consistent, whether they are sold in the EU or elsewhere (Vogel, 2012). Large cosmetics producers such as Revlon, Unilevel and L'Oreal, have similarly reformulated all their products to be REACH-compatible, while Estee Lauder uses a single safety standard for 95\% of its production (Vogel, 2012). These examples show that scale economies associated in a single global production process therefore often allow the EU to effectively dictate the global product standards.

Only this type of non-divisibility-the importance of scale economies-has traditionally been associated with the California Effect. However, non-divisibility comes in various forms. Legal and technical non-divisibility similarly steer companies toward uniform standards. Legal non-divisibility can be seen in global

\footnotetext{
9 See Commission Regulation 1907/2006, of the European Parliament and of the Council of 18 December 2006 Concerning the Registration, Evaluation, Authorisation and Restriction of Chemicals, 2006 O.J. (L 396) 1 (hereinafter REACH).
} 
mergers, which cannot be consummated on a jurisdiction-byjurisdiction basis-the most stringent competition jurisdiction gets to determine the fate of the transaction worldwide (Bradford, 2011). One of the most famous examples of the EU's global regulatory clout was its decision to prohibit the $\$ 42$ billion proposed acquisition of Honeywell International by General Electric. ${ }^{10}$ When the EU blocked this transaction involving two U.S. companies, it was irrelevant that the U.S. competition authorities had previously cleared the transaction: the acquisition was banned worldwide as it was legally impossible to let the merger proceed in one market and prohibit it in another. Similarly, the EU often gets to dictate the code of conduct for dominant companies worldwide. For example, the EU has imposed record-high fines and behavioral remedies against dominant U.S. companies, including Microsoft and Intel. ${ }^{11}$

Technical non-divisibility often applies for the regulation of privacy. For example, the EU forces companies like Google to amend their data storage and other business practices to conform to European privacy standards (Mitchener, 2002; Gray et al., 2008). ${ }^{12}$ Facing a technical difficulty to isolate its data collection for the EU, Google is forced to adjust its global operations to the most demanding EU standard. Another example involving technical non-divisibility is the EU's emissions trading scheme ("ETS"), a cornerstone of the EU's climate change policy. The ETS entails that all airlines, including foreign ones, have to buy emission permits for all their flights that depart from or land at European airports. ${ }^{13}$ This way, airlines cannot limit their compliance to the part of the journey that takes place in the European airspace, making the scheme non-divisible. For instance, on a flight from San Francisco to London, only nine percent of the emissions are calculated to occur in the EU airspace (twenty-nine percent, thirty-seven percent, and twentyfive percent of the emissions occurring over the US, Canada, and the high seas, respectively). ${ }^{14}$ Yet the airline must acquire emission permits for each ton of emissions released across the entire flight since the point of landing is the EU else pay a fine or, even more severely, could be banned from European airports.

Of course, the line between a technical and economic nondivisibility can at times be blurred. In principle, American Airlines flying from San Francisco to London could technically divide its journey and make a stopover on some island in the Atlantic Ocean in order to shorten the journey that becomes subject to obligations under the ETS. However, this would lengthen the duration of the flight and make the service less competitive and hence less valuable. Technical non-divisibility problem would hence be replaced by economic non-divisibility problem. Another feature of technical non-divisibility is that its existence may create new incentives for corporations to develop products or technologies that can better be divided. Even if technology companies cannot today separate all internet searches for technical reasons, such difficulties may be overcome with new technological developments.

A particularly interesting example of non-divisibility-partly technical and partly economic type-comes from the EU's strict

\footnotetext{
10 Case COMP/M.2220 General Electric/Honeywell (July 3, 2001); in contrast, see Press Release U.S. Dept. of justice, Justice Department Requires Divestitures in Merger between General Electric and Honeywell (May 2, 2001), available at: http://www.justice.gov/atr/public/press_releases/2001/8140.pdf.

11 COMP/37.990 Intel (May 13, 2009); COMP/C-3/37.792 Microsoft (2004).

12 See Legal Confusion on Internet Privacy: The Clash of Data Civilizations, Economist, June 17, 2010, at 2 available at: http://www.economist.com/node/16377097.

13 Directive 2008/101/EC of the European Parliament and of the Council of 19 November 2008 amending Directive 2003/87/EC so as to include aviation activities in the scheme for greenhouse gas emission allowance trading within the Community (OJ 2009 L 8, p. 3).

${ }^{14}$ Statement of Nancy N. Young, 'The European Union's Emissions Trading Scheme: A Violation of International Law' (July 27, 2011) 4, at: http:// republicans.transportation.house.gov/Media/file/TestimonyAviation/2011-07-27-\%
} 20Young.pdf. regulation of Genetically Modified Organisms ("GMOs"). At first glance, it appears that GMOs should be divisible and thus not amenable to the Brussels Effect. In principle, U.S. farmers could separate their production and cultivate both GMO and non-GMO varieties destined for domestic and export markets, respectively. Yet such division can be difficult in practice. The GMO crops must be segregated from the time they are planted throughout the processing and marketing chain. This entails separating growing areas and preventing pollen drift from GMO fields to non-GMO fields. ${ }^{15}$ Producers and distributors must also use separate equipment, storage areas, and shipping containers, and establish trait identification systems that allow for the tracking of produce from the farm to the consumer (Hanrahan, 2010). The specific processes through which U.S. farmers gather and transport their crops for distribution often make their harvests inseparable in practice (Young, 2003). At the minimum, separation of production is costly. This technical and economic non-divisibility of GMO production has led some farmers to choose to forgo the risks and costs of separation, and converge to the strictest standard by only cultivating EU-approved GMO crops-irrespective of where these crops are sold (Young, 2003; Vogel, 2012).

However, when products do not call for a uniform standard, such as when markets are divisible or scale economies insufficient to justify a uniform standard, the EU can at best achieve compliance with its standard but not globalization of those standards. Seen this way, divisibility sets clear boundaries to the market power that any given jurisdiction can wield. Car manufacturers are responding to different national and regional emission standards with diversified technologies in an effort to minimize risks and maximize returns. DVDs offer another example. They have different region codes allowing film distributors to segregate release dates, content restrictions, and price across regions. Thus, the Brussels Effect is unlikely whenever the firm's costs of customizing its conduct or production to different rules are low. Labor markets are also divisible, as long as scale economies do not require the producer to concentrate production into a single production location. Adhering to one global minimum wage across jurisdictions, for instance, entails few scale economies. A corporation can maintain different standards in different jurisdictions without difficulty-ranging from working hours and vacation policies to retirement plans and collective labor strategies in different jurisdictions. When employing labor in Europe, foreign firms have to follow the EU's labor rules, which does not preclude them from being able to take advantage of divergent (and presumably lower) standards in their home markets.

The above discussion reveals that the emergence of a global regulatory power requires the presence of both exogenous and endogenous conditions. The global economic environment determines the relative market power whereas the technological developments and corporations' business practices determine the existence or inexistence of non-divisibility. These are factors that are largely exogenous and hence less of a product of a political process that determines what to regulate and how. In contrast, regulatory capacity, preference for strict standards and the choice to regulate inelastic targets reflect built-in policy choices by individual governments. Some governments invest in building regulatory institutions whereas others do not see these institutions as a priority. The government's decision to regulate inelastic targets with strict standards is even more clearly a political choice, which in most countries reflects underlying preferences of the citizenry. These exogenous factors, combined with those are "chosen" by the jurisdiction, together determine the global

\footnotetext{
15 See Case C-442/09 Karl Heinz Bablok and Others v Freistaat Bayern (September 6
} 2011). 
distribution of regulatory power and bestow the EU as the most influential regulator in the world.

\section{The EU's motivations for supplying global standards}

The EU's exercise of global regulatory clout can spring from various motivations-both external and internal. Some commentators argue that the EU's external policies reflect "imperialistic" objectives (Zielonka, 2008; Kogan, 2005) whereas others emphasize the EU's role as a benevolent hegemon (Manners, 2002). This Section argues that the charges of regulatory imperialism are misguided when seeking to explain the origins of the Brussels Effect. A more compelling account suggests that the EU is guided primarily by internal motivations stemming from its need to preserve the single market without undermining the competitiveness of European companies. That the Brussels Effect does not reflect primarily an external agenda does not, however, mean that such an agenda is missing altogether. The EU has numerous other ways to pursue global regulatory harmonization. This Section explains when and why the EU relies on the Brussels Effect to do the work of regulatory harmonization and, conversely, when and why it resorts to more active political means to accomplish its regulatory agenda.

\subsection{External motivations}

In contrast to the U.S.'s unilateralism in international affairs, the EU is often portrayed as a champion of multilateral cooperation and universal norms (Rubenfeld, 2004). However, the EU's commitment to multilateralism and universalism must be qualified. The EU is an influential global player with the ability and the willingness to shape the international order to its liking. It seeks to vigorously promote its interests in the global stage, both unilaterally and multilaterally. In doing so, the EU acts like any great power with the desire to ensure that international norms reflect its preferences (Bradford and Posner, 2011).

Some scholars suggest that the EU's motivations are imperialistic-that the EU is, in fact, seeking to exert political and economic domination over other countries. The EU does have significant leverage over countries that seek closer cooperation with, or eventually membership in, the EU. The EU also actively exports its standards through bilateral agreements-most glaringly, though accession agreements and partnership treaties. But even outside of its immediate sphere of influence, critics maintain that the EU is engaged in a novel form of imperialism. Instead of pursuing its goals through military and political instruments, the EU has been accused of relying on economic and bureaucratic tools of dominion over countries that are dependent on access to its vast domestic market. ${ }^{16}$ Lawrence A. Kogan, criticizing the EU's extensive regulatory reach in environmental and food safety matters, puts it bluntly: "[T]he EU has embarked upon an adventure in environmental cultural imperialism. This is a global practice reminiscent of an earlier European colonial era. And the fact that Europe is using "soft power" to do it hardly makes it more palatable to people who will be unable to feed themselves as a result" (Kogan, 2005; Drucker, 2005).

While critics claim that the EU is exporting its standards without the consent of other states, the EU counters that it is not engaged in coercion-it is simply enforcing the norms of the single market equally on domestic and foreign players and merely asking others to play by its rules when operating on its home market. The EU further legitimizes its strategies by claiming that its values and policies are normatively desirable and universally applicable (Stiglitz,

\footnotetext{
16 See, e.g., Regulatory Imperialism, WALL ST. J., Oct. 26, 2007 at 1; see also Europe v. U.S. Business, WALl ST. J., Jan. 17, 2008.
}

2007; Manners, 2008). ${ }^{17}$ Seen in this light, the EU's externalization of its regulatory preferences reflects altruistic purposes of a benign hegemon. As a champion of norms that serve global welfare, the EU wants to create a rule-based world and offer an alternative to the more controversial and self-serving worldview advanced by the U.S. A commitment to a social welfare state and a cautious attitude toward risk guides the EU's global agenda and steers it toward extensive regulation of the global economy-the protection of the environment, health care, precaution in the field of biotechnology, and various welfare rights. By emphasizing the universal benefits of its global regulatory agenda, the EU often succeeds in obscuring the de facto unilateralism that drives its implementation. Yet even if the EU was able to portray itself as a benevolent, normative power that is advancing universal norms (Manners, 2002; Leonard, 2005; Smith, 2005), skeptics point out that the notion of a normative power has neo-colonial undertones as the EU is exporting its "standards of civilization" (Nicolaidis and Howse, 2002; Diez, 2006).

The EU's active role in the fight against climate change presents one example of regulation that is presumably driven by largely benevolent motives. Climate change is a global problem that requires a global response. The EU has a limited capacity to mitigate climate change alone if other states continue to emit greenhouse gases into the atmosphere. The EU has led efforts to conclude a new and more potent global climate change treaty. Yet the difficulties associated with international treaty negotiations have given the EU the imperative to act unilaterally. The EU's defense of its unilateral regulation is that it is acting in the collective interest to provide a global public good: mitigation of climate change.

The EU's own experience in creating a common market reinforces the EU's willingness to pursue a global order based on predictable rules. In forming the EU, the Member States retained their sovereignty. The only way to bind them to the common European enterprise was to have them adhere to common rules designed to create an internal market. More regulation meant more predictability and stability. This has fostered a belief within the EU that an extensive regulatory system is needed to preserve global public goods. The EU takes the view that trade liberalization without simultaneous harmonization of policies fails. This, for the EU, offers the most efficient and universally valid model of economic and political integration (Zielonka, 2008).

The EU also emphasizes the strong democratic backing for its regulatory stance. The European Commission has described the EU's commitment to further its social agenda as part of its trade policy as "forging collective preferences"-cultivating the idea that the EU is indeed concerned about the social effects of economic integration and justifying its measures against foreign entrants as legitimate policies reflecting social choices made collectively by Europeans (Meunier and Nicolaidis, 2006; Habermas, 2006; Ruggie, 1982). ${ }^{18}$

In the end, any entity that is willing to shape the international order-whether for self-serving or more altruistic motives-must do so with the means available to it. In the case of the EU, regulatory power is all it has. Lacking traditional means of power, the EU's greatest global influence is accomplished through the norms that it has the competence to promulgate. In the absence of military power or unconstrained economic power, the EU can exercise genuine

\footnotetext{
17 See Art. 3(5) of the Consolidated version of the Treaty on European Union; See also Jose M. Barroso, [the president of the European Commission], Europe's Rising Global Role, in http://www.project-syndicate.org/commentary/ europe-s-rising-global-role (Project Syndicate, Dec. 18, 2009).

18 Arguing that social regulation is part of the European tradition. This is often
} referred to as an "embedded liberalism" compromise. 
unilateral power only by fixing the standards of behavior for the rest of the world (Laïdi, 2007).

\subsection{Internal motivations}

For those skeptical of the EU's benevolent motives, the EU is simply seeking to level the playing field by exporting its costly regulations abroad under the guise of concern for consumer and environmental health and safety (Kogan, 2005). According to the Czech president Vaclav Klaus, "the claims for quasi-universal social rights are disguised ... attempts to protect high-cost producers in highly regulated countries, with unsustainable welfare standards, against cheaper labor in more productive countries" (Zielonka, 2008).

A concern for EU corporations' competitiveness offers a compelling explanation for the EU's global regulatory agenda. Europe is committed to the welfare state and the sustainability of its economic policies. Yet the failure to export its standards to others would put European firms at a competitive disadvantage. By acting as a global regulator, the EU can defend its social preferences without compromising the competitiveness of its industries. The worry about EU airlines' competitiveness was explicitly included as a rationale to include foreign airlines into the EU's emissions trading scheme (Rahim, 2011). If foreign companies adhere to EU norms on the European market, the import-competing industries are assured a level playing field. If the EU's norms further spread to third countries, the EU can ensure that its export-oriented firms are not disadvantaged in those markets. This account of the EU's motivations is particularly persuasive when one focuses on the private interests as drivers of the EU's regulatory policies and assumes that regulators are responsive to these interests.

The push for externalization of EU standards is reinforced by a peculiar constellation of domestic politics, whereby environmentalists or consumer advocates and corporations join forces in lobbying for the globalization of EU standards. While often in disagreement, both environmentalists and corporate interests benefit from the EU imposing its standards on foreign firms. Environmentalists gain broader adherence to norms that they support-many of which have an inherently global character. At the same time, EU corporations gain a level playing field whereby foreign firms do not gain a competitive advantage at their expense (DeSombre, 2000). Thus, the EU has a particularly powerful incentive to act externally when the moral and economic imperatives of the community coincide-when it enjoys political rents from EU industry and the consumer and environmental advocates at the same time (Vogel, 1995).

The EU's external regulatory power further serves the bureaucratic interests of the European Commission. Through extensive use of its regulatory powers, the Commission compensates for the lack of power it otherwise has in external affairs. The Commission's legal competence to act on its Member States' behalf in foreign policy or security-related matters is limited and subject to unanimity among the Member States. On issues relating to the single market, the EU's legal authority is at its broadest. Exercising the regulatory authority also involves low costs. Regulations are not constrained by budgetary appropriations and are hence not dependent on the tax revenues available to the Community institutions. Given that the EU's budget amounts to only around 1\% of the GDP of the EU, the Commission has limited options to pursue policies that involve direct budgetary expenditures. Thus, the only way for the Commission to exert influence without extensive financial resources is to engage in regulatory activity. The cost of implementing and enforcing regulations often fall on the governments of the individual member states while the cost of complying with these regulations is primarily borne by firms and individuals as targets of the EU regulations. In the absence of traditional powers of states to tax and spend (not to mention wage a war), it may not therefore be surprising that the Commission has built an empire of laws and regulations (Majone, 1994).

Yet perhaps the most compelling narrative views the EU's external influence simply as an accidental byproduct of its internal motivations. The supranational regulatory apparatus was created to establish and oversee an integrated, liberalized, and competitive market in Europe. This institutional capacity was a response to internal challenges driven by a political agenda that was inwardlooking. Inconsistent domestic regulations were seen to threaten the single market, prompting the need for harmonization. The importance of preserving the single market has also driven various regulations that do not directly serve the goals of economic integration. For instance, the EU's expanded regulatory authority in consumer and environmental matters was created to reassure the European public that economic integration would not be pursued at the expense of consumer and environmental protection. Rather than aiming to provide global environmental standards, the EU was thus concerned with the legitimacy of the single market program (Vogel, 2012). Acknowledging the primacy of these internal motivations also suggests that the EU's external influence is not compromised during times when it is turned inwards-the external power flows directly from the EU's pursuit of its internal goals.

While the primary objective of European regulatory activity has been to create and guard the single market, this activity has had the ancillary effect of establishing the EU as a global regulatory hegemon. This external dimension of the single market was only fully realized when the EU's trading partners expressed concerns that the single market might impose costs on third countries (Gstohl, 2007). Of course, the EU-in particular its institutions representing the Community interest on the world stage-benefits from such "incidental externalities" that follow from the EU's pursuit of the Community's internal regulatory agenda. These actors likely welcome the EU's newfound external regulatory power, however unintended its origin.

Indeed, some may argue that it is impossible today to disentangle the relative importance of internal and external motivations as drivers of the EU's regulatory agenda. But what is distinctive to the Brussels Effect is that it describes the external impact of regulations that the EU would have enacted anyway in order to accomplish the internal objectives related to the single market. Of course, the awareness of the external impact of its regulations-once established-can lead the EU to use the Brussels Effect as an argument to convince any reluctant interest groups within the EU to go along with its regulatory agenda. Being able to show that the EU companies' international competitiveness is not compromised when undertaking new regulatory burdens shows how the Brussels Effect can be linked to the EU's internal objectives.

Over time, it is plausible that the EU's internal goals are gradually giving way to a more multi-faceted set of goals-both internal and external-that the EU pursues in setting its regulatory policy today. Still, it is the internal goals relating to the need to harmonize regulations within the EU that provide the most powerful explanation for the origins of, and the motivations for, the Brussels Effect.

\subsection{Market-driven versus political harmonization}

The EU is not always passive or unintentional in its exercise of global regulatory power. Similarly, the Brussels Effect is not the sole manifestation of the EU's global regulatory influence. At times, EU rules diffuse through voluntary legislative borrowing by other states or through various benchmarking mechanisms (Sabel and Zeitlin, 2008; Linos, 2011). These methods may require little involvement by any EU institutions. The EU also actively exports its standards through bilateral agreements-most glaringly, though accession agreements and partnership treaties-or, in more 
extreme instance, relies on economic sanctions or other forms of coercion to pursue its policy goals (Smith, 2003; Hufbauer et al., 2009; Meunier and Nicolaidis, 2006). ${ }^{19}$

These other methods of externalizing EU standards have been discussed elsewhere and will not be reviewed here. Instead, the below discussion focuses on explaining why the logic underlying the Brussels Effect often represents a more attractive means for the EU to externalize its standards on foreign actors when compared to accomplishing the same via political harmonization. At the same time, it also explains why and when-these advantages of the Brussels Effect notwithstanding-the EU continues to engage in regulatory harmonization via its political agency as well.

Market-driven harmonization has a distinct advantage over political harmonization: it entails low contracting costs and limited enforcement costs. In relying on unilateral measures, the EU is not forced to seek the consent of other states. Unilateralism avoids the need to overcome collective action problems. It also obviates the need to extend costly transfer payments or to undertake costly coercive measures toward countries reluctant to join a treaty or an institution. The EU can also forgo the uncertainties associated with the ratification of treaties by foreign legislators. The EU's recent unsuccessful efforts to further the WTO's Doha Round negotiations and the UN-led process to negotiate a new global climate change treaty reveal the difficulties associated with multilateral cooperation. These processes have required extensive political capital and diplomatic efforts and yielded few results. Instead of engaging in burdensome diplomacy to endorse its standards, market-driven harmonization allows the EU to outsource the lobbying to foreign firms who often become advocates for higher standards in their own home markets after having incurred compliance costs in the EU.

The EU's unilateral regulatory agenda is more easily implemented as it requires the cooperation of foreign corporations willing to trade in its market rather than cooperation by foreign sovereigns. A contrast can be drawn to the efforts of the U.S. Securities and Exchange Commission and the U.S. State Department to enforce U.S. rules on insider trading. These efforts were complicated by the reluctance of foreign countries, particularly Switzerland, to cooperate with the United States due to their domestic laws on bank secrecy. The United States has had to spend extensive political capital to persuade Swiss authorities to cooperate. This was considered worth the effort given that Swiss banks hold approximately half of the world's private assets (Macey, 2003). The United States' ability to curtail domestic insider trading would have been compromised had it not secured a change in the domestic rules of a foreign country. Merely incentivizing foreign corporations operating in the United States to cooperate was not sufficient to meet this goal.

Political harmonization is particularly difficult if states do not agree on the benefits of global standards. But multilateral standardsetting is difficult even if most states agree on the desirability of uniform standards. States often have different views on the optimal standard to which they should converge. Different points of convergence entail different distributional consequences, making some states prefer one standard over another (Bradford, 2007). Unilateral regulatory globalization solves such coordination problems: the most stringent rule becomes the focal point of convergence. A mutual understanding that the EU can retain its standards at no cost provides a predictable and stable equilibrium.

Perhaps most importantly, market-driven harmonization provides the most efficient form of regulatory globalization because the EU can rely on its existing domestic institutions to enforce its regulations. Treaties are distinctly difficult and expensive to enforce. When a strict global standard is a product of an international treaty, there is no guarantee that the treaty will be implemented and enforced. Indeed, some commentators have noted that treaties producing "effectively enforced international standards are the exception rather than the rule" (Vogel and Kagan, 2004).

The EU has not abandoned multilateralism in favor of unilateralism in all instances. The EU also maintains an active political agenda that is geared at international regulatory harmonization. The EU's persisting, if selective, reliance on multilateral rules and political institutions may be surprising given the many benefits embedded in unilateral globalization. Yet there are certain instances where market-driven harmonization is not enough, prompting the EU to seek affirmative adoption of regulation by foreign regulators. When above-discussed conditions for unilateral harmonization are not present, no Brussels Effect takes place-whether de jure or de facto. In these situations, multilateralism is often the only path to regulatory globalization.

The theory underlying the Brussels Effect offers predictions on when the EU is likely to pursue political harmonization. The EU would be expected to seek political harmonization in situations where it cares about international standards and where the Brussels Effect fails to reach EU corporations' important export markets. In the absence of a level playing field, the EU's export-oriented firms may have difficulties penetrating these markets. Thus, when the EU is a net exporter as opposed to a net importer of a certain product, the EU is expected to care more about the standard of the export market than that of its home market. Further, it is precisely then that the Brussels Effect is least likely to automatically ratchet the standard up, since net importer countries have a smaller presence in the EU. The EU is therefore likely to expend diplomatic efforts to negotiate multilateral standards in areas where it is a net exporter and rely on markets in areas where it is a net importer.

The EU may also be motivated to encourage third countries to adopt certain standards if its internal regulatory objectives would be compromised by more lenient standards elsewhere. This is true when actions of other countries produce negative externalities that adversely impact Europe, such as when China's failure to limit its greenhouse gas emissions directly compromises the EU's efforts to halt climate change. Another example would be the EU's efforts to convince other countries to adopt tough domestic competition laws (Bradford, 2007). The deterrent effect of the EU's competition laws can be compromised if members of a cartel are able to offset high EU fines by reaping supracompetitive profits in markets that fail to control their collusive practices. ${ }^{20}$ Foreign standards may also reinforce the desired effect of EU standards. For example, when standards are characterized by network effects, the benefits relative to the costs of adopting a standard increase when several countries have the same standard (Vogel and Kagan, 2004).

The EU may also seek to encourage third countries to adopt its standards in cases where it is acting out of a moral imperative. If the EU is motivated by a moral quest to change behavior globally-e.g., promote human rights-unilateral globalization is rarely sufficient. This is particularly likely when the issue is salient to influential domestic political groups that seek to export an ideology or moral convictions and when they care about establishing standards for universal conduct (Macey, 2003).

Finally, at times the EU may pursue political harmonization even when market-driven harmonization is taking place. This may reflect willingness to "lock-in" certain EU standards by

\footnotetext{
19 See Communication from the Commission to the Council and the European Parliament: Wider Europe-Neighbourhood: A New Framework for Relations with Our Eastern and Southern Neighbours, at 5, COM (2003) 104 final (Mar. 11, 2003).
}

20 See, e.g., F. Hoffmann-La Roche Ltd. v. Empagran S. A., 542 U.S. 155, 169 (2004). 
institutionalizing them. ${ }^{21}$ This can be a shrewd way to preempt a future state of the world where market access will be a less effective tool for the EU to exert influence. The EU is also often successful in incorporating its standards into international organizations, making the benefits of unilateralism over multilateralism less stark. Being a construction of intergovernmental cooperation itself, the EU has extensive experience in promulgating rules that lend themselves to adoption by heterogeneous states. The EU is also skillful in using its institutional structure-being a hybrid between state and a federation-to its advantage. In international negotiations, it can leverage the negotiating power of twenty-eight countries while also using the same number strategically as a constraint when portraying itself as an agent whose hands are tied and who can therefore only sign onto a set of policies that pass the various domestic veto points (Safrin, 2008).

Market-driven and political harmonization can also take place in sequence. The EU is better able to institutionalize its standard if a limited Brussels Effect has already taken place: a set of countries exporting into the EU already follow the EU standard, whether de jure or de facto. The EU may seek to reinforce this trend by requiring its standards to be adopted as a condition for closer economic and political relationships with the EU, increasing its sphere of influence within its neighborhood. These developments allow the EU to reach a critical mass that tips the balance in Europe's favor in any international efforts to reach an agreement on harmonization of certain regulations (Bradford, 2007).

\section{The motivations for adopting global standards}

This Section explains why foreign corporations have adopted EU regulations even when they would have preferred an alternative rule. It also explains why foreign governments have been unable to constrain the EU's regulatory agenda or interfere with the markets' ability to entrench EU norms across jurisdictions.

\subsection{The reluctant emulation of EU standards}

In many instances, the EU policies impose adjustment costs on foreign corporations. Foreign consumers also often end up paying more for goods when producers are forced to accommodate concerns that their domestic consumers do not necessarily share. For this reason, most foreign corporations, supported by their governments, vehemently oppose EU regulations. The European chemical regulation, the "REACH," is an example. As the regulation applies to approximately 30,000 chemicals, its impact on the $\$ 600$ billion U.S. chemical industry is profound (Kogan, 2005; Shapiro, 2004). The critics claim that REACH imposes significant costs and challenges on manufacturers and importers, particularly related to the supply chain, sales, and procurement. At worst, the regulation is said to impede innovation and the development of new substances due to fears that they would not meet the more stringent European requirements (Pouillot et al., 2009).

Notwithstanding their resistance of EU rules, foreign corporations often adopt the EU norms as the "golden standard" that governs their global operations. As long as corporations' conduct or production is non-divisible across markets, these corporations are driven to conform their conduct or production to a single global rule. Their choice as to which standard to adopt is determined

\footnotetext{
21 Commission Staff Working Paper: Implementing Policy for External Trade in the Fields of Standards and Conformity Assessment: A Tool Box of Instruments, at 8, SEC (2001) 1570 final (Sept. 28, 2001)); see Communication from the Commission to the Council, the European Parliament, the European Economic and Social Committee and the Committee of the Regions: A Single Market for Citizens, COM (2007) 60 final (Feb. 21, 2007).
}

by the relative stringency of the standards across relevant regulators. By choosing to adjust its business practices to the most demanding standard-typically the EU standard-a corporation can typically ensure its compliance with all regulations that it confronts when operating in multiple jurisdictions. Of course, if the adjustment costs exceed the benefits of operating on that market, the corporation likely forgoes access to that market. However, the adjustment is likely whenever the market in question is an important source of consumer demand. In particular, this is the case when the demand in the corporation's home market or in alternative third markets is inadequate and the opportunities for diverting trade to those markets is therefore limited. This way, while this corporation would have initially preferred another rule, the logic of participating in international economic activity-not any coercive measures imposed by the EU-steers the corporation toward EU standards.

This distinct nature of the Brussels Effect-a phenomenon falling somewhere between cooperation and coercion-distinguishes it from conventional theories on regulatory globalization. At times, countries with lenient regulatory standards have an incentive to adopt other countries' stricter standards in order to attract foreign capital (Simmons, 2004). This was the case with, for instance, the U.S. capital adequacy requirements and accounting standards for public offerings. This type of voluntary emulation of strict standards amounts to a market-driven race to the top that is normatively desirable-the followers have a clear economic incentive to adopt the desirable rules that leave everyone better off. In contrast, unilateral regulatory globalization is rarely a process of voluntary harmonization: foreign corporations would often prefer another rule but find it rational to adjust nonetheless given the opportunity costs of not doing so. Yet the EU is not coercing others to adopt its rules either. Market forces are sufficient to create "involuntary incentives" to adjust to the rules of the strict regulator. In other words, unilateral regulatory globalization entails the dominant jurisdiction imposing an incentive to adjust, followed by reluctant emulation by market participants.

However, some foreign stakeholders may welcome the EU's extensive regulatory activity. U.S. consumers who prefer higher levels of consumer protection and a civil society that advocates environmental protection often seize EU policies and use them in their attempts to forge change in the U.S. (Young, 2003; Scott, 2009). These groups welcome the EU's unilateralism, hailing the EU as the benevolent provider of global public goods in situations where their own governments or multilateral cooperation mechanisms fail to provide them.

Multinational U.S. corporations may have also a mixed reaction to EU regulation. When trading across the common market, they benefit from facing a single EU standard instead of 28 different national standards, even if that standard was higher than the average standard before the upward harmonization took place in the EU. This way, EU regulations can be seen as coordination devices that reduce complexity and enhance predictability. U.S. corporations can also seize business opportunities in third markets in situations where the EU bans certain products or production methods domestically but where there is still demand for those products in third markets. In these markets where the Brussels Effect has failed to take hold, U.S. producers are likely to face less competition from EU producers.

The intensity of U.S. corporations' opposition to EU rules also likely depends on whether they are large, export-oriented producers or small, non-export-oriented producers (Milner, 1998). If an export-oriented U.S. firm is forced to adjust its global production to the (presumably more costly) EU-standard, the non-exportoriented U.S. firm gains a competitive advantage in the firms' home market (the only market in which the non-exporting firm operates). The small non-exporting firm thus welcomes the de facto Brussels Effect. However, these firms' interests are reversed with respect to 
a possible de jure Brussels Effect. An export-oriented U.S. firm often has the incentive to advocate the EU standard in its home market after having already adjusted to the EU-standard. It benefits from leveling the playing field at its home market at no additional cost to itself. In contrast, a non-export-oriented U.S. firm is likely to resist the de jure Brussels Effect as it benefits from retaining its competitive advantage over the firm conforming to the EU standard. Thus, the relative influence of export-oriented and non-export oriented firms will impact the U.S.'s response to the Brussels Effect.

Finally, the EU provides a forum for U.S. producers to challenge their competitors' practices under EU competition rules. For example, U.S. corporations have found the EU a valuable legal battle ground and frequently engage in forum shopping when they seek to halt practices of their (often domestic) competitors. U.S.based United Technologies was the principal complainant in the $\mathrm{GE} /$ Honeywell merger investigation after having lost its acquisition bid to GE. It was also a U.S. company that brought charges against Microsoft in the EU, knowing that it was more likely to obtain remedies in the EU, which harbors a broader notion of what constitutes anti-competitive conduct. As the tables turned, Microsoft lodged a competition complaint before the European Commission against Google.

Whether these foreign stakeholders embrace or oppose the Brussels Effect, they have the incentive to invest considerable resources in trying to influence regulatory outcomes in the EU. Indeed, given the global reach of the EU's regulatory actions, lobbying activity is particularly salient in Brussels as the benefits available from the possible regulatory capture of the Commission or another EU institution is expected to exceed the benefits of successfully influencing any other regulatory agency with lesser global clout.

\subsection{The difficulty of counterbalancing the $E U$}

Some progressive states in the U.S., most notably California, have occasionally endorsed the EU's leadership. The EU's chemical regulation is an example of California's willingness to follow the EU's regulatory lead (Scott, 2009; Pohl, 2004). For these states, the EU can be a catalyst and a resource that helps them in their pursuit of domestic regulatory reforms. Some developing country governments similarly welcome the Brussels Effect. If these countries have the desire, but limited resources, to provide safer products for their consumers, they benefit from the EU standards that affect production patterns globally. The Brussels Effect presents these countries with an opportunity to outsource their regulatory pursuits to a more resourceful agency. For example, developing country competition agencies often free-ride on the EU's competition investigations, benefiting from the global effects of the EU's decision to ban anti-competitive mergers or force firms to amend their conduct and products globally.

Even if there are occasional foreign beneficiaries from EU regulations, most foreign governments are reluctant to cede their power to regulate the behavior of their corporations to a foreign regulator. These governments, including the U.S., have an incentive to constrain the EU. The U.S. frequently views the EU's regulatory policies as inefficient and detrimental to its welfare-in addition to being counter-majoritarian and thus undemocratic. If we assume that the existing domestic regulation in the U.S. is efficient in the sense that it maximizes national welfare and reflects domestic political equilibrium, any deviation from that standard entails costs. Firms need to reorganize their production processes or practices in order to comply with another standard (Drezner, 2005). Governments incur costs relating to legislating and retraining its regulators (Drezner, 2005). And, most importantly, the U.S. must forgo the efficiencies that its preferred regulation would generate.
The U.S. government has often voiced its opposition to the external effect of the EU's regulatory agenda. For example, prompted by the American chemicals industry, the U.S. government engaged in extensive efforts to block the EU's regulation of chemicals. ${ }^{22}$ U.S. reaction to the EU's interventionist competition laws has been equally hostile (Murray et al., 2001). And the recent plan to subject foreign airlines to the EU's ETS system has been fervidly opposed by U.S. airlines and the U.S. government, as well as other foreign governments (Murray et al., 2001; Chaffin and Parker, 2011).

Yet there is very little that the U.S. can do to stop the EU from regulating its domestic market. In this sense, the Brussels Effect differs starkly from the California Effect. California cannot promulgate regulations that are inconsistent with the federal laws in the U.S. absent an explicit waiver from the U.S. federal government. But there is nothing akin to a doctrine of pre-emption that constrains the EU's regulatory powers. ${ }^{23}$ When U.S. producers are forced to either comply with higher standards or be shut out of the EU market, the U.S. has four ways to respond: (1) choose voluntarily to converge to the EU standard; (2) try to compel the EU to change its rules, such as by resorting to diplomacy, suing the EU in the WTO, or offering the EU some rewards or threatening the EU with sanctions; (3) seek a cooperative solution, such as by pursuing an international standard that reflects some combination of US and EU preferences; or, finally, (4) choose to do nothing.

A challenge for the U.S. is that it often gains nothing by defending its standard even if that standard was more efficient. As a less stringent regulator, the U.S. simply becomes obsolete in the fields where the de facto Brussels Effect takes place. But the U.S. is unlikely to adopt the EU standard as a regular course of action, either. When holding onto its own domestic standards, the U.S. can at least ensure that its standard governs the activity that is domestic in nature. And given how large the U.S. market is, this often provides an adequate incentive to stick to its preferred regulation domestically absent overwhelming lobbying by domestic export-oriented industries to the contrary.

The most controversial strategy for the U.S. or any other foreign government would be to threaten the EU with sanctions. The EU's decision to include foreign airlines into its ETS scheme, for example, has provoked threats that foreign carriers may forgo European Airbus planes in favor of competing US-based Boeing planes (Michaels, 2012; Chaffin, 2012). However, the prospect of a trade war is often too costly for the countries themselves to pursue as a strategy. In many instances, the proposed trade sanctions would also be inconsistent with the countries' obligations under the WTO. In past U.S.-EU competition enforcement conflicts, for instance, the U.S. threatened the EU with trade sanctions unless the EU backed down (Coleman, 1997). Yet notwithstanding the escalated rhetoric of retaliation, the competition controversies led the U.S. government to concede that "we have no power to change EU law."24

At times, international institutions have provided the most effective venue to challenge the EU regulations. The WTO law prevents countries from restricting imports from countries with less stringent regulations unless the restriction is necessary to protect public health or related to conservation of the environment. The U.S. did resort to the WTO in challenging the EU's prohibition on

\footnotetext{
22 See H.R. Comm. On Government Reform (Minority Staff) A Special Interest Case Study: The Chemical Industry, the Bush Administration, and the European Regulation of Chemicals (April 1, 2004), available at: http://www.democrats. reform.house.gov/Documents/20040817125807-75305.pdf.

23 See 42 U.S.C. § 7543(a) (2006). See also Letter from Stephen L. Johnson, Administrator, EPA, to Arnold Schwarzenegger, Governor of California (Dec. 17, 2007), available at: http://ag.ca.gov/cms_attachments/press/pdfs/n1514_epa-letter.pdf.

24 See Deborah Majoras, Deputy Assistant Attorney Gen., Antitrust Div., U.S. Dep't of Justice, GE-Honeywell: The U.S. Decision, Remarks Before the Antitrust Law Section, State Bar of Georgia, November 29, 2001.
} 
GMO food and hormone-treated beef, eventually winning its core claims in both trade disputes. ${ }^{25}$ Despite these victories, the WTO offers, at best, imperfect remedies. The WTO dispute settlement mechanism is characterized by weaknesses such as non-retroactive sanctions. In addition, the WTO system cannot compel a member state to lift its restrictive measures. It can merely authorize sanctions against a non-compliant member state. For instance, the EU has maintained its import-ban on hormone-treated beef, preferring to endure U.S. retaliation. The EU has also repeatedly allowed the deadline for implementing the GMO-ruling to lapse, while the U.S. has suspended its retaliatory measures in anticipation of settlement or the EU's future compliance (Hanrahan, 2010). These difficulties the U.S. has faced in obtaining EU's compliance suggests that the WTO provides even less relief for the EU's weaker trading partners. Authorizing a small developing country to punish its powerful trading partner hardly guarantees that this right will be used.

The WTO's ability to constrain individual countries' regulations is further limited by its restricted mandate. The WTO bans discrimination between importers and domestic producers. Yet many of the EU regulations, while perhaps costly to foreign producers, are not discriminatory in their nature: EU companies are subject to the same rules. If the EU regulations have no disparate impact on foreign producers, allegations of protectionism are difficult to maintain. The WTO can do little to restrain such regulations that are costly yet not protectionist in their object or effect. Further, many areas-such as competition and privacy regulations-do not fall within the purview of the WTO rules and its dispute settlement mechanism in the first place. There have been several attempts to include competition, among other new issue areas, under the WTO framework. All those attempts have failed (Bradford, 2011). And expanding the scope of the WTO to new issue areas is even more unlikely today as the consensus among over 150 countries that rarely agree on the content of the rules is increasingly beyond reach.

Indeed, the WTO does not only fail to adequately constrain the Brussels Effect; at times it may even help to facilitate it. The WTO rules limit the ability of the EU's trading partners to respond to EU regulatory pursuits with unilateral retaliation. Had the U.S., for instance, imposed trade sanctions on the EU when faced with the EU's data transfer ban, it would have violated the WTO rules and subjected itself to a WTO complaint by the EU. In this sense, the WTO can also provide a shield for, and not only a limitation to, the Brussels Effect (Schaffer, 2000).

\section{Conclusion}

This Article has highlighted the unprecedented global power that the EU exercises through its legal institutions and standards that it successfully exports to the rest of the world via the Brussels Effect. Without resorting to international institutions or seeking other nations' cooperation, the EU is able to promulgate regulations that become entrenched in the legal frameworks of developed and developing markets alike, leading to the "Europeanization" of important aspects of global commerce.

The occurrence of the Brussels Effect depends on the presence of specific conditions that allow the EU to forgo political harmonization and let the markets convert its regional standards into global standards. This Article has sought to identify those conditions and, with an enhanced understanding of those conditions, explain why

\footnotetext{
25 See Appellate Body Report, EC Measures Concerning Meat and Meat Products (Hormones), WT/DS26/AB/R, WT/DS48/AB/R, adopted 13 February 1998, DSR 1998:I, 135 ; Panel Report, European Communities - Measures Affecting the Approval and Marketing of Biotech Products, WT/DS291/R, WT/DS292/R, WT/DS293/R, Add.1 to Add.9, and Corr.1, adopted 21 November 2006, DSR 2006:III-VIII, 847.
}

some regulations, but not others, can be externalized via market forces alone. It has disputed the notion that the market size alone is conducive to gravitating companies toward the dominant jurisdiction's standards. Instead, a single jurisdiction can passively export its standards only when it also has the regulatory capacity and regulatory propensity to regulate inelastic targets with strict and non-divisible standards. This explains why the EU is currently the only regulatory regime that can wield unilateral influence across a number of areas of law and why other large economies, including the US and China, lack this kind of power.

This discussion has been descriptive, intentionally omitting the normative inquiry on whether the Brussels Effect is socially desirable. It seems evident that corporations are not necessarily adjusting to EU standards because of the prospect of mutual gains or some Pareto-improving outcome. If existing regulations in other jurisdictions are optimal, the Brussels Effect is likely to lead to inefficiently high overall global regulation, adversely affecting global welfare. But the Brussels Effects may also lead to an efficient outcome. If existing regulations in other jurisdictions are too permissive or weakly enforced, unilateral regulatory globalization might be a desirable means of overriding sub-optimally low regulations elsewhere. The overall welfare effects of this phenomenon are thus difficult to disentangle.

For some, the Brussels Effect may also raise concerns of democratic accountability. The idea that unelected European civil servants have the ability to determine what kind of products are produced for the U.S. markets and thus how much protection American consumers thus need can be disconcerting to those involved. However, others might claim that the Brussels Effect does not undermine U.S. democracy. The EU's regulatory reach may have the effect of balancing the overrepresentation of business interests in American public life by empowering consumers (Keohane, 2009). These are some of the normative questions that this Article raises but intentionally leaves for others.

The acknowledgment of the existence and influence of the Brussels Effect has implications on how we think about power and the question of who is powerful and why. If you were to ask national security experts whether the EU is powerful, they would probably say no. If you were to ask economist whether the EU is powerful, they would probably discuss how the relative power of the EU is diminishing with the rise of China. But if you were to ask GE, Microsoft, Google, Monsanto, Dow Chemical, or Revlon whether the EU is powerful, the answer would be a resounding (and likely bitter) yes.

One key question is what type of power matters today. Much of international relations discussion has until the recent past been preoccupied by the traditional notion of military power. Yet the utility of military power is declining (Gelb, 2010). Economic concerns usually prevail over military imperatives. In the world of multiple powers and heterogeneous interests, exercise of unilateral economic power is rarely possible. The inability to conclude the WTO trade talks is one reminder that in the world where many are powerful, nobody alone is powerful enough to get anything done. Economic sanctions are rarely successful today because embargoed nations have an easier time finding alternative suppliers or markets for their products. Conditional aid and other rewards, traditionally used by powerful nations and institutions like the World Bank and International Monetary Fund as means of leverage, are decreasingly effective as countries like China are prepared to extend aid to rogue and needy countries-no strings attached.

When power is defined in terms of the actual influence that a country can wield, the EU's ability to penetrate vast areas of global commerce is relevant. Contrary to traditional contours of influence, the Brussels Effect captures a phenomenon where the EU does not have to do anything except regulate its own market to exercise global regulatory power. The size and attractiveness of its market 
does the rest. By virtue of being the world's largest trading block, the EU can dictate what is traded. It is one of the few areas of influence where unilateralism still works. Regulatory power is a less costly, more deployable, and more durable type of power. Also, unlike other forms of power, it cannot easily be undermined by others.

Another advantage of regulatory power is its ability to generate leverage that has the greatest impact with the lowest political profile. Many of the regulations appear technical but often have major implications on countries, corporations, and consumers around the world. Conflicts over regulatory power rarely elevate to the political level. Trade is a much less controversial way of pursuing foreign policy objectives in particular when the EU can always, in principle, offer the choice of not complying with its rules. Subscribing to EU rules is the price of trading with Europe. All the EU is doing is exercising its right to protect its own consumers. This is a less controversial position to take compared to a regime change pursued in the name of laudable goals such as democracy or human rights. Thus, in falling between coercion and cooperation, regulatory power strikes a balance of legitimacy and potency that makes it a more efficacious option than its alternatives.

The EU's regulatory clout shows that the EU can be a superpower without a super state. It is a shrewd and influential actor that projects its values and makes the world to its liking by playing to its strengths. While the EU portrays itself as a champion of multilateralism, it is selectively supporting multilateralism in areas where it lacks unilateral power. The more the EU bolsters the authority of the UN Security Council, the more the EU can constrain the exercise of unilateral power by the U.S. But when it comes to the regulation of global markets, the EU can rely on its markets and hence be less concerned about pursuing multilateral, institutional cooperation.

The somewhat surprising outcome is that the EU's increasing regulatory clout and its impact on U.S. businesses may lead the U.S. to support greater oversight by international institutions. Though often skeptical of international institutions' ability to regulate the markets, the U.S. may come to see international cooperation as an opportunity to play a shared, rather than obsolete, role in the regulation of global commerce. This might resemble the idea of "pre-emptive federalism," whereby the U.S. may seek international regulation as a means to prevent the Brussels Effect. Having some influence over regulatory standards is better than ceding influence to the EU altogether. The impending negotiations to create a Transatlantic free trade area ${ }^{26}$ form this type of rare opportunity for the US to try to persuade the EU to rein in its regulatory standards. Given the low level of existing transatlantic tariff barriers, the gains from the prospective free trade agreement are expected to stem from the parties' ability to overcome their existing regulatory differences. But this, of course, requires that the EU be prepared to forgo unilateralism for jointly set standards, enhancing EU's bargaining power in the negotiations.

Another implication of the Brussels Effect is that it challenges the primacy of the narrative that the EU is a "normative power" that leads by example. The EU is often viewed as a power that relies on persuasion to change "hearts and minds" and thereby the preferences and identities of other actors. The EU is regularly portrayed as a new type of power that steers away from coercion and relies instead on positive incentives and soft power. ${ }^{27}$ This Article has not argued that those propensities of influence are not within the

\footnotetext{
26 See U.S., EU Announcement on Negotiations on a Transatlantic Trade and Investment Partnership (February 13, 2013), available at: http://www.ustr.gov/about-us/ press-office/press-releases/2013/february/statement-US-EU-Presidents.

27 See Hugh Richardson, Head of the Delegation of the European Commission to Japan, Speech at Waseda University, The European Union and Global Governance symposium: Smartening the EU's Soft Power (May 16, 2008).
}

EU's repertoire of influence. Yet this Article has focused on what is a vast, unappreciated, and perhaps the most controversial aspect of the EU's global role: the EU's unilateral employment of tools of soft coercion that go against the preferences of its trading partners.

Another question is how long lasting this type of unilateral regulatory globalization is. With advances in technology, it is possible that goods become increasingly divisible in the future. ${ }^{28}$ It is likely to become technologically feasible and economically viable to produce a greater range of product varieties to serve the different consumer tastes and regulatory requirements prevailing in different markets. The acknowledgment of the Brussels Effect should further incentivize companies to develop technologies that allow for greater divisibility at lower costs. Such a development, to the extent that it applies to a significant number of product markets, may gradually erode the EU's ability to exert global regulatory clout in the future.

Also the EU's ability to promulgate new rules may diminish over time. As the EU's regulatory powers grow, divisions within the EU also grow. It becomes harder for the EU to pass new regulations amidst the growing heterogeneity of its population. One salient example is that the EU has been unable to create a common energy policy despite the EU member states' collective vulnerability to energy insecurity (Laïdi, 2007). Enlargement magnifies this problem as preferences within the EU become more diverse while the EU institutions fail to adjust to more complex decision-making.

Today, the EU faces a distinctive challenge to its authority. The concurrent deepening and widening of the EU's agenda has already created severe constitutional crises within the EU, with the difficulties surrounding the euro further testing the limits of solidarity within the union. The EU is criticized both for mandating painful austerity on debtor countries and imposing forced solidarity on creditor countries. As a result, both sets of countries feel alienated from the EU. The great political divide in Europe today is not between the right and the left but between those who are turned inwards and those who embrace globalization and further integration. The former would scale back the powers transferred to the EU in the name of reinstating the sovereignty of European nations. Fearful of these demands, even the integrationists are growing more timid in their calls for expanding EU powers at the expense of national sovereignty. More European regulation means less sovereignty. And less sovereignty means more unpredictability and loss of control akin to the crises surrounding the common European currency. Thus, the growing gap between these different visions within Europe for Europe, in the end, presents perhaps the greatest challenge to the European external regulatory agenda.

To add to the internal political challenges, the economic and geo-political reality outside Europe is changing. Over time, the EU's regulatory clout may begin to erode as the emerging markets increase in the size and affluence of their consumer base. Today, corporations are rarely able to carve out the EU as a market for their products and services and divert trade elsewhere. But as demand in places like China grows, the businesses' dependence on their access to the EU market is diminishing. It is difficult to imagine a future state of the world where genuinely multinational companies like GE would choose to forgo trade in Europe and thus avoid clearing its transactions and conduct with EU's competition authorities. But the opportunities for trading elsewhere will increase, reducing the opportunity costs of forgoing the European market at least with respect to some products and activities. China will increasingly be in a position to offer an alternative destination for various goods if European standards make it too costly for businesses to trade there.

\footnotetext{
${ }^{28}$ A Third Industrial Revolution, the Economist (April 21, 2012).
} 
Still, the growing might of Chinese consumers is an imperfect threat, at best, to the near term ability of the EU to continue on its chosen path. It will be a while before China could replace the EU as a source of de facto global standards. China's regulatory capacity and the willingness to elevate the protection of consumers and the environment over the pursuit of growth are not growing with the speed of its economy. While China has banned a few high profile global mergers (Zhang and Yanhua Zhang, 2010), ${ }^{29}$ it has by no means overtaken the European Commission as the most ardent guardian of competitive markets. And while China may soon be the largest consumer market, GDP per capita is a better prediction of a country's regulatory propensity than is overall GDP (Vogel and Kagan, 2004). Affluence and social regulation are often correlated, suggesting that domestic demand for high levels of regulation is likely to be weak for some time to come. By the time China might be able to overtake the EU as a de facto global regulator, the EU might already have entrenched its norms in other jurisdictions and institutions and changed the way business is conducted in a lasting way.

\section{Acknowledgments}

This Article was written for the Workshop on Law, State and Development, held at the University of Florence. Special thanks to the workshop participants, in particular the organizers and editors of this volume, Eric Brousseau and Jerome Sgard, as well as the commentators Adrienne Héritier and Debin Ma, for their excellent feedback. I am also grateful for the anonymous reviewers for their helpful suggestions. Valuable comments were also provided by Lucas Bergkamp, George Bermann, Travis Bradford, Rachel Brewster, Tim Büthe, Grainne DeBurca, Lee Fennell, Jacob Gersen, Tom Ginsburg, Victor Goldberg, Michael Graetz, Todd Hendserson, Aziz Huq, Suzanne Kingston, Katerina Linos, Richard McAdams, Jay Modrall, Henry Monaghan, Jide Nzelibe, Nathaniel Persily, Katharina Pistor, Eric Posner, Tonya Putnam, Charles Sabel, Joanne Scott, Anne-Marie Slaughter, and David Vogel, as well as the participants of the workshops held at Columbia Law School, Duke Law School, and University of Chicago Law School. I am grateful to Taimoor Aziz, Brandon Ceranowicz, Elliott DeRemer, Peter Dietrich, Christodoulus Kaoutzanis, Pauline Phoa, and Mark Sater for their excellent research assistance. A longer version of this Article, entitled "The Brussels Effect," was published in 107 Northwestern University Law Review 1 (2012).

\section{References}

Bach, D., Newman, A.L., 2007. The European regulatory state and global public policy: micro-institutions, macro-influence. J. Eur. Pub. Policy 14, 827-841.

Barroso, J.M., 2009, December 18. Europe's Rising Global Role, Project Syndicate. http://www.project-syndicate.org/commentary/europe-s-rising-global-role

Bradford, A., 2011. In: Elhauge, E. (Ed.), Antitrust Law in Global Markets. Research Handbook on the Economics of Antitrust Law. , 308 pp.

Bradford, A., 2007. International antitrust negotiations and the false hope of the WTO. Harv. Int. Law J. 48, 383-439.

Bradford, A., Posner, E.A., 2011. Universal exceptionalism in international law. Harv. Int. Law J. 52, 1-54.

Braithwaite, J., Drahos, P., 2000. Global Business Regulation. Cambridge University Press, pp. 518-519.

Büthe, T., Mattli, W., 2010. International standards and standard-setting bodies. In: Coen, D., et al. (Eds.), The Oxford Handbook of Business and Government, vol. 440, pp. 448-463.

Büthe, T., Mattli, W., 2011. The New Global Rulers: The Privatization of Regulation in the World Economy.

Chaffin, J., 2011. Business attacks transaction tax plan. Fin. Times September 28 6:36 PM, Available at: http://www.ft.com/intl/cms/s/0/f9d2188a-e9ec11e0-a149-00144feab49a.html\#axzz1rOJUmpsd

${ }^{29}$ For example, Chinese officials rejected Coca-Cola's attempted acquisition of Huiyan Juice Group for $\$ 2.4$ billion.
Chaffin, J., 2012. EU defies carbon war threats. Fin. Times March 20.

Chaffin, J., Parker, A., 2011. Blow to US airlines in the emissions fight Fin. Times October 6 http://www.ft.com/cms/s/0/36556726-f005-11e0-bc9d00144feab49a.html\#axzz1zmDeQR5

Coffee, J.C., 2002. Racing towards the top? The impact of cross-listings and stock market competition on international corporate governance. Columbia Law Rev. 102,1757-1831.

Coleman, B., 1997. Clinton Hints U.S. may retaliate if EU tries to block BoeingMcDonnell deal. Wall St. J. July 18

Damro, C., 2012. Market power Europe. J. Eur. Pub. Policy 19 (5), 628-699.

DeSombre, E., 2000. Domestic Sources of International Environmental Policy: Industry, Environmentalists, and U.S. Power.

DeSombre, E., 2006. Flagging Standards: Globalization and Environmental, Safety and Labor Regulations at Sea.

Diez, T., 2006. Europe's others and the return of geopolitics. Camb. Rev. Int. Aff. 17 319-335.

Drezner, D.W., 2005. Globalization, harmonization, and competition: the different pathways to policy convergence. J. Eur. Pub. Policy 12, 841-859.

Drucker, P.F., 2005. Trading places. Natl. Int. Spring, 101-107.

Gelb, L., 2010, November/December. GDP Now Matters More than Force, Foreign Affairs. http://www.foreignaffairs.com/articles/66858/leslie-h-gelb/gdp-nowmatters-more-than-force

Gray, T., 2008. US and EU authorities review privacy threats on social networking sites. Entertain. Law Rev. 19, 69-74.

Gruber, L., 2000. Ruling the World: Power Politics and the Rise of Supranational Institutions.

Gstohl, S., 2007. Political Dimensions of an Externalization of the EU's Interna Market. Dep. EU Int'l Rel. Dipl. Stud., 4, EU Diplomacy Papers, Available at: http://aei.pitt.edu/9593/1/EDP_3-2007_Gst\%C3\%B6hl.pdf

Guasch, J.L., Hahn, R.W., 1999. The costs and benefits of regulation: implications for developing countries. World Bank Res. Observer 14, 137-158.

Habermas, J., 2006. Why Europe needs a constitution. In: Rogowski, R., Turner, C. (Eds.), The Shape of the New Europe.

Hanrahan, C.E., 2010, April 8. Agricultural Biotechnology: The U.S.-EU Dispute. Congressional Research Service.

Harrell, S., 2010. Beyond REACH? An analysis of the European Union's chemica regulation program under world trade organization agreement. Wisc. Int. Law J. 24, 471-522.

Holzinger, K., Sommerer, T., 2011. 'Race to the Bottom' or 'Race to Brussels'? Environmental competition in Europe. J. Common Market Stud. 49, 315-339.

Hufbauer, G.C., et al., 2009. Economic Sanctions Reconsidered.

Keleman, R.D., Vogel, D., 2007, September. Trading Places: The US and the EU in International Environmental Politics, Available at: http://www.princeton. edu/ smeunier/kelemen\%20vogel\%20trading\%20places\%20sept\%2007.pdf

Keohane, R.O., et al., 2009. Democracy-enhancing multilateralism. Int. Org. 1 63.

Kogan, L.A., 2005. Exporting Precaution: How Europe's Risk-Free Regulatory Agenda Threatens American Free Enterprise, at 95 Washington Legal Foundation, Available at: http://www.wlf.org/upload/110405MONOKogan.pdf

Laïdi, Z., 2007. The unintended consequences of European power. Les Cahiers europeens de Sciences Po 8, Available at: http://www.cee.sciences-po. fr/erpa/docs/wp_2007_5.pdf (accessed 08.08.11).

Lazer, D., 2011. Regulatory interdependence and international governance. J. Eur. Pub. Policy 8, 474-492.

Leonard, M., 2005. Why Europe Will Run the 21st Century

Linos, K., 2011. Diffusion through democracy. Am. J. Polit. Sci. 55, 678-695.

Lofsted, R.E., Vogel, D., 2001. The changing character of consumer and environmental regulation: a comparison of Europe and the United States. Risk Anal. 21, 399-416.

Macey, J.R., 2003. Regulatory globalization as a response to regulatory competition. Emory Law J. 52, 1353-1379.

Majone, G., 1994. The rise of the regulatory state in Europe. West. Eur. Politics 17 77-101.

Manners, I., 2002. Normative power Europe: a contradiction in terms? J. Common Market Stud. 40, 235-258

Manners, I., 2008. The normative ethics of the European Union. Int. Aff. 84 (1), 45-60.

Meunier, S., Nicolaidis, K., 2006. The European Union as a conflicted trade power. J. Eur. Pub. Policy 13, 906-925.

Michaels, D., 2012. Chinese envoy urges airlines to shun buying airbus planes. Wal St. J. May 12.

Milner, H., 1998. Resisting Protectionism: Global Industries and the Politics of International Trade.

Mitchener, B., 2002. Standard bearers: increasingly, rules of global economy are set in Brussels-to farmers and manufacturers, satisfying EU regulators becomes a crucial concern-from corn to SUV ‘Bull Bars'. Wall St. J. April 22.

Murphy, D.D., 2004. The Structure of Regulatory Competition: Corporations and Public Policies in a Global Economy.

Murray, M., et al., 2001. Oceans apart: as honeywell deal goes awry for GE, fallout may be global-the U.S. giant's troubles in Europe could chill mergers of multinationals-raining on Welch's parade. Wall St. J. June 15.

Nicolaidis, K., Howse, R., 2002. This is my EUtopia: narrative as power. J. Common Market Stud. 40, 767-792.

Pohl, O., 2004. European environmental rules propel change in U.S. N. Y. Times July 6.

Pouillot, A., et al., 2009. REACH: impact on the US cosmetics industry? J. Cos. Derm. $8,3-7$. 
Rahim, S., 2011. U.S.-E.U. showdown over airline emissions begins today. N. Y. Times July 5, Available at: http://www.nytimes.com/cwire/2011/07/05/ 05climatewire-us-eu-showdown-over-airline-emissions-begins-88684.html? pagewanted $=$ all

Rubenfeld, J., 2004. Unilateralism and constitutionalism. N. Y. Univ. Law Rev. 79, 1975-2028.

Ruggie, J.G., 1982. International regimes, transactions, and change: embedded liberalism in the postwar economic order. Int. Org. 36, 379-415.

Sabel, C.F., Zeitlin, J., 2008. Learning from difference: the new architecture of experimentalist governance in the EU. Eur. Law J. 14, 271.

Schaffer, G., 2000. Globalization and social protection; the impact of the EU and international rules in the ratcheting up of U.S. privacy standards. Yale J. Int. Law $25,1-88$.

Schapiro, M., 2004. New power for 'Old Europe'. The Nation December 27.

Scharpf, F.W., 1996. Negative and positive integration in the political economy of European welfare states. In: Marks, G., et al. (Eds.), Governance in the European Union.

Scheer, D., 2003. Europe's new high-tech role: playing privacy cop to the world. Wall St. J. October 10 .

Scott, J., 2009. From Brussels with love: the transatlantic travels of European law and the chemistry of regulatory attraction. Am. J. Comp. Law 57, 897-942.

Safrin, S., 2008. The un-exceptionalism of U.S. exceptionalism. Vand. J. Transnatl. Law 41, 1307-1354.

Sherwoord, B., 2005. Long arm of the US regulator. Fin. Times March 9.

Simmons, B., 2004. The international politics of harmonization: the case of capital market regulation. In: Vogel, D., Kagan, R.A. (Eds.), Dynamics of Regulatory Change: How Globalization Affects National Regulatory Policies, vol. 42, pp. $50-52$.
Smith, K.E., 2003, European Union Foreign Policy in a Changing World.

Smith, K.E., (European Foreign Policy Unit Working Paper) 2005. Still Civilian Powe EU. London School of Economics.

Spar, D., Yoffie, D.B., 2000. A race to the bottom or governance from the top? In: Prakash, A., Hart, J.A. (Eds.), Coping with Globalization. , pp. 31-51.

Stiglitz, J., 2007, March 29. The EU's Global Role, Guardian.co.uk. Available at: http://www guardian.co.uk/commentisfree/2007/mar/29/theeusglobalmission

Swire, P.P., 1996. The race to laxity and the race to undesirability: explaining failures in competition among jurisdictions in environmental law. Yale Law Policy Rev. 14, 67-110.

Tonelson, A., 2000. The Race to the Bottom: Why a Worldwide Worker Surplus and Uncontrolled Free Trade Are Sinking American Living Standards.

Vogel, D., 2012. Politics of precaution, regulating health, safety, and environmenta risks in Europe and the United States.

Vogel, D., 1997. Trading up and governing across: transnational governance and environmental protection. J. Eur. Pub. Policy 4, 556-571.

Vogel, D., 1995. Trading Up: Consumer and Environmental Regulation in a Globa Economy.

Vogel, D., Kagan, R., 2004. Introduction. In: Vogel, D., Kagan, R.A. (Eds.), Dynamics of Regulatory Change: How Globalization Affects National Regulatory Policies.

Wirth, D.A., 2007. The EU's new impact on U.S. environmental regulation. Fletche Forum World Aff. 31, 91-106.

Young, A.R., 2003. Political transfer and trading up? Transatlantic trade in genetically modified food and U.S. politics. World Pol. 55, 457-484.

Zhang, X., Yanhua Zhang, V., 2010. Chinese merger control: patterns and implications. J. Compet. Law Econ. 6, 477-496.

Zielonka, J., 2008. Europe as a global actor: empire by example? Int. Aff. 84 471-484 